\title{
Indonesian learners in Australian education environment: perceptions, challenges, and resilience
}

\author{
Diana Purwati ${ }^{*}$ (1) https://orcid.org/0000-0001-9111-2830 \\ Arnis Silvia2 ${ }^{2}$ https://orcid.org/0000-0001-7296-6267 \\ ${ }^{1}$ School of Education, University of South Australia, Australia \\ ${ }^{2}$ School of Arts, University of South Australia, Australia
}

\begin{abstract}
With the economic development of Indonesia in the recent years, there has been a large number of Indonesian students continue their higher education in overseas countries, particularly Australia. Hence, examining their perceptions, challenges and experiences to adapt to the Australian English learning environment becomes an interesting attribute to explore. Drawing on this issue, the in-hand study explores how Indonesian learners dealt with challenges and difficulties in Australian education environment. Employing a qualitative research, this study involved eight Indonesian learners enrolled in English language programs in a number of Australian universities. Using interview as the instrument, the findings showed that the participants perceived a positive perception toward the communication activities during the teaching and learning practices; however, they encountered some difficulties related to grammar instruction within communicative practice. The results of interview further revealed that most of the learning difficulties they experienced were due to their prior exposure and habit to Indonesian teaching and learning styles. The participants further conveyed that enhancing English ability and building confidence were two most possible ways to deal with the difficulties. These results contribute as fruitful insights for teachers to be aware of different learners' styles and needs, particularly those coming from various cultural backgrounds, so that they could engage in more interactive teaching and learning activities.
\end{abstract}

\section{ARTICLE INFO \\ Keywords:}

Indonesian ESL learners; learners' perception; Australian education environment

\section{Article History:}

Received: 07 March 2021

Revised: 29 March 2021

Accepted: 30 March 2021

Published: 03 April 2021

How to Cite in APA Style: Purwati, D. \& Silvia, A. (2021). Indonesian learners in Australian education environment: perceptions, challenges, and resilience. Journal of Educational Management and Instruction, 1(1), 1-8.

\section{Introduction}

With the increase of economic development of Indonesia in the recent years, there has been a growing number of Indonesian students pursuing their higher education in overseas countries, particularly Western countries such as United States, the United Kingdom, Germany, Australia, and New Zealand (Fenanlampir et al., 2019; Mulyana \& Murtiningsih, 2017). By the year goes, the number of Indonesian students in overseas countries is continuously increasing with at least thirty-five thousands learners every year (Efendi et al., 2020). According to the data of Quick Count Achievement SUN Education in 2018 (de Britto, 2019), there were five favorite countries that become destination for most Indonesian students, i.e. Australia, United States, England, Singapore, and China. The result of quick count is interesting since Australia becomes the most favorite country destination to study for Indonesian students overwhelming the United States (de Britto, 2019). According to International Student Enrollment Data (2016), Indonesia is among the top ten foreign countries having students in Melbourne, Victoria, Australia. 
The growing number of Indonesian students continue their education in Australia has attracted attention from a number of scholars (Nguyen, 2011; Yu \& Wright, 2016; Zulferdi, 2021). These studies have examined learning achievements and challenges of Indonesian students when having engaged in Australian education environment. A lot of Indonesian students spent time at Language centers to learn and practice language before entering universities (Dewi, 2017). The cultural adaptation from traditional background to a new environment in an English native country became a crucial issue faced by most of Indonesian learners (Scarino, 2012). Indonesian students were found to usually brought along their learning habits and styles from their original country when they experience education in Australia (Zulferdi, 2021). This becomes an initial and primary problem for Indonesian learners to deal with new teaching styles conducted in Australian education environment. Hence, Indonesian learners' perceptions, challenges, and resilience becomes an interesting attribute to explore.

Research on international learners' perspectives, challenges, and experiences in other countries' education systems has been conducted with various results. The majority of these studies was conducted in the context of United States education system (Mitchell Jr et al., 2017; Mukminin, 2012; Lopez \& Bui, 2014) and European learning contexts (Du et al., 2017). The results of these studies revealed international students' perceptions and experiences during studying in Western countries. The issue of cultural differences and language efficacy was found to be the most frequently faced challenge by international students including Indonesian (Mukminin, 2012). More recently, the study of Mitchell Jr et al. (2017) further showed that international students were highly influenced by their cultural and language origin having significantly different exposure to the Western culture and language such as in United States and Europe.

Studies have also been conducted to examine international students' perceptions and challenges in Australian higher education context (Paton, 2007; Sawir, 2005; Sawir et al., 2012). The results indicated that language-related issues was a primary difficulty faced by international students. More precisely, the problem was likely associated with students' English language proficiency (Sawir et al., 2012). When it comes to Indonesian students, the study of Novera (2004) found that they were difficult to adapt to Australian learning environment due to linguistics and academic challenges. It was further explained that learning experiences in their home country seemed to affect their learning styles in the host country. Thus, it is highly necessary to explore their beliefs and perceptions about learning experiences in other countries, particularly Australia where most of Indonesian students go to.

Having reviewed previous literature about perceptions and experiences of international students in their host countries, two research gaps are observable. First, most of the precedent studies were conducted in the context of United States and Europe learning environment; hence, slightly did we find the perceptions, experiences, and challenges of Indonesian students in Australian education context. Second, the majority of previous studies highly concerned on beliefs, challenges, and experiences of International students having a study in the host country. Thus, to the best of the authors' knowledge, research on their resilience and the ways they deal with the challenges of studying abroad still remain a paucity of evidence. Examining their beliefs, experiences, and resilience to deal with the challenges of studying abroad is crucial to identify the students' needs and interests so that they are able to involve in an effective teaching and learning activities.

As an attempt to close the gaps, the present study aims to explore Indonesian students' perceptions, challenges, and resilience of having a study in Australian university learning environment. By involving eight Indonesian students studying at English language programs of several universities in Australia. Using interview, the views and perspectives of the Indonesian students are scrutinized to reach the objective. This study depicts an in-depth understanding of how Indonesian students deal with 
education environment in Australia. The results of this study contribute to providing fruitful insights for educators to adopt better approach and design learning instructions that suit the learners' needs and interests. Indonesian students are stereotyped as "passive learners" when studying in other countries in most of previous studies (Ambrose et al., 2017; Nguyen, 2011; Novera, 2004).

\section{Method}

\section{Research context and participants}

This study aims to explore International students' perceptions, challenges, and resilience of having study abroad in Australian education environment. Using convenient sampling technique, this study recruited eight Indonesian students (namely P1-P8) studying at English language programs of several universities I Australia. They came from various regions in Indonesia and were pursuing higher education in the levels of Master and doctoral degrees. Their age was between 25 and 40 with average age 32 . The English proficiency among the participants was varied ranging from 5.5 to 7.5. The differences indicated that they might have various cultural and educational backgrounds as well as English language abilities. Table 1 presents the demographic information of the participants.

Table 1. Demographic Information of the Participants

\begin{tabular}{llllll}
\hline Participant & Gender & Age & $\begin{array}{l}\text { Degree majoring/ } \\
\text { applying in }\end{array}$ & $\begin{array}{l}\text { IELTS } \\
\text { score }\end{array}$ & $\begin{array}{l}\text { Length of study } \\
\text { (in months) }\end{array}$ \\
\hline P1 & F & 32 & Master of TESOL & 6.0 & 18 \\
P2 & F & 25 & Master of TESOL & 5.5 & 10 \\
P3 & M & 36 & $\begin{array}{l}\text { Ph.D in Applied } \\
\text { Linguistics }\end{array}$ & 7.5 & 35 \\
& & & & \\
P4 & F & 28 & $\begin{array}{l}\text { Master of Applied } \\
\text { Linguistics }\end{array}$ & 7.3 & 24 \\
P5 & M & 29 & Master in TESOL & 7.0 & 12 \\
P6 & F & 40 & Ph.D in TESOL & 6.5 & 12 \\
P7 & M & 29 & Master in Applied & 7.0 & 18 \\
P8 & & & Linguistics & & \\
\hline
\end{tabular}

\section{Instrument and data collection}

The data was gathered by means of semi-structured interviews to reach an indepth understanding of Indonesian learners' perceptions, challenges, and resilience on studying in Australian education environment. The interview consisted of two sections. The first section dealt with participants' personal information such as name, age, gender, IELTS score, study major, and length of the study in Australia. The second section comprised main interview questions seeking the answers for the participants' perceptions, challenges, and resilience of studying in Australian education context. The interviews were conducted either in Bahasa Indonesia or English, depending on the participants' preferences so that they could freely express their views and ideas without worrying their English. Each interview was last for about 30 - 40 minutes and was conducted by face-to-face interaction or by phone because of the distance issue. The whole interview process was audio-recorded and transcribed, and translated into English for the purpose of data analysis and interpretation.

\section{Data analysis}

The data obtained from the interviews were analyzed by employing a bottom-up (inductive) approach. The data were classified into three main categories based on the theme of the research problems, i.e. perceptions, challenges, and resilience. In the process of data analysis, the researchers performed coding toward the emerging patterns and themes. Furthermore, the researchers classified, reviewed, and synthesized 
the emerging themes that further used as a basis of conclusion drawing. To ensure the validity and reliability of the data and the whole research process, one of the researchers developed the instrument and the other researcher checked and evaluated it. Moreover, the two researchers performed transcription and coding of the data independently and performed stages of discussion to reach the final agreement of the data conclusion. Simultaneously, the data analysis process was also verified using a deductive approach in which relevant literature was revisited then exploring the emerging themes as salient to the topic of the research.

\section{Results}

This section highlights the results of data analysis with regards to the three primary themes, i.e. perceptions, challenges, and resilience. The most representative quotes from the participants' utterances are presented to strengthen the description of the findings. Interpretation and implication of the results and how the findings correlate to current theories and previous results are also presented as a discussion.

\section{Indonesian learners' perceptions on Australian education environment}

The first theme of the finding about Indonesian learners' perception on studying in Australian education environment was related to the learning aims and objectives. The results showed that Indonesian learners considered that there were different English learning aims and objectives between in Indonesia and Australia. Most of Indonesian students felt that passing the exam was the primary goal of learning English. On the contrary, they recognized that the ultimate goals of English teaching and learning in Australia focused on how to use English as a means of communication rather than to deal with exams. As P1 and P4 said:

"I experience learning English in Junior and Senior high schools and mostly my teachers taught us about grammar and how to pass the exams. Therefore, our English communication skills are less trained since the focus of the exams is on grammar and language structure" (P1).

"Teaching and learning English in Australia emphasize on how to use English to communicate to others. Therefore, developing learners' autonomy to use the language is the primary goal" (P4).

The second theme of the finding was about the learning environment. The result suggested that Indonesian learners generally perceived positive impressions about the learning environment in several Australian universities. Six out of the ten learners described the learning atmosphere as open and interactive, while the other two participants said that the learning environment was relaxed and enjoyable. In addition, three of the participants mentioned that small number of students in a class helps them to be focus and create a cooperative environment for discussion and practice. They confessed that a lot of communication took place between teachers and students and it could enhance their motivation to involve in learning activities. As P6 said:

"Overall, I feel that English learning here [in Australia] more concern on how to use the language as communication vehicle. In the class, I experience a lot of practices and exposures in the language because the instructors facilitate cooperative learning activities" (P6).

The third theme of the finding was about teacher and learner roles. The result indicated that the participants believed that the roles of teacher and learner were different in Indonesian and Australian contexts. They further revealed that in Indonesia, teachers were usually had full authorities over classroom and acted as transmitter of knowledge. By this context, students were to be passive receptors. Meanwhile in Australian classroom, teachers considered themselves as facilitators who provided 
exposures and support for their learners. Learners were granted role as active participants and kept their own responsibility of learning. As P7 said:

"In Indonesia, teachers have full control of the class and act as the transmitter of knowledge, so that we mostly learn about grammatical rules. While in Australia, students are given a lot of exposures to practice English with teachers as the facilitators" (P7).

\section{Indonesian learners' challenges in Australian education environment}

Although the participants believed that English learning activities in Australian education setting were beneficial, they considered several challenges to deal with. According to the interview data, some challenges raised such as dealing with high pressure of academic writing, using grammar in context, complexity of the Australian accent, oral communication, and demand for autonomy. The majority of the participants mentioned that writing became the most challenging skill since they were demanded to have good ability of English writing. As P3 said:

"I am poor at grammar and this is crucial skill when we have to write English. Most of courses here need writing skill such as doing assignment, even when we have to present in front of class, we should create the writing version before presenting" (P3)

Moreover, the Australian accent of English seemed to be a further problem for Indonesian learners. One of the participant said that he often missed particular information when having communication with native speakers both in campus environment and in public places. As P5 said:

"During the English teaching and learning in Indonesia, we focus on grammar and literacy skills so communicative competence of the language seems to be weak. While in Australia, the English learning focus on how to use English for communication. Also, because of the native speakers' accent, I often misunderstand conversation with native here both in campus and in other public places" (P5).

P1 and P8 added that sometimes they encountered difficulty when they had to independently seek for particular materials or knowledge where originality and creativity were highly necessary in Australian context. Being international learners in Australia required competency to be an active and autonomous learner.

"Here [in Australia], we have to research on our own about materials and knowledge to support the explanation or presentation given by the instructors. For me, it is challenging and takes some time to deal with" (P1)

"..... I think it [to be an autonomous learner] is also challenging when we must be aware of independent learning. Most of learning activities in Australia should be done independently to maximize the inputs" (P8).

\section{Indonesian learners' resilience toward the challenges in Australian education}

Along with the challenges, the participants were also asked to explain about their resilience to deal with these challenges. The interview data showed that practices and building confidence were the alternative solution to enhance their English and adapted to the Australian learning environment. The majority of the participants mentioned that enhancing English ability was a must for them to actively participate in classroom learning activities and to improve the efficacy of daily communication. To do so, they told that building a confidence was highly necessary. As three of the participants said:

"... and to deal with these difficulties we have to improve the ability of English especially our communication skills" (P7)

"I think the possible solution that I will do is having practices English as much as possible. It may be done with increasing communication with native speakers here as well as building my confidence to speak in English" (P3) 
"We have proverb 'the more the practices the better the knowledge'. I think it is proper to deal with the difficulties about learning English. Practice is the most effective way to enhance language proficiency and have a success as international learners in this country [Australia]" (P6)

\section{Discussion}

This study has explored how Indonesian learners perceive English language learning activities, challenges, and their resilience during studying abroad in Australia. According to the findings, Indonesian learners hold positive perceptions toward academic atmospheres in Australian learning environment. However, they find language issue and autonomous learning as the most significant challenges. The findings also illustrate that having more practices and building confidence in using English as a means of communication are the possible solution offered by the Indonesian learners.

So, what do the findings imply for us? For sure, all learners might be affected by what they have been experienced previously (Hembrough \& Jordan, 2020; Nugroho \& Atmojo, 2020). In this case, Indonesian learners have to adapt to learning environment in Australian context, but they seem to be greatly influenced by their learning styles in Indonesia before continuing higher education in the host country. This finding confirms the results of Dewi (2017) and Novera (2004) that Indonesian learners perceive positive perceptions of studying in Australia, but encounter several challenges such as language accent and learning autonomy. In a wider context, the result further supports what have been found by Nguyen (2011) that south-east Asian students (Thailand, Vietnam, and Indonesia) seem to consider the issue of language ability and cultural differences as the primary challenges of studying abroad, not only in Australia but also in most of English speaking countries. This findings are closely related to previous studies that explain about the cultural influences into language learners' acquisition (Lai et al., 2016; Nugroho \& Rekha, 2020).

With regards to the participants' resilience toward these challenges, this study found that having continuous practices and building self-confidence are the possible solution that Indonesian learners can do. This finding is consistent to the results of Naghdipour (2017) and Nugroho (2020) that language learners need to practice as much as they can to obtain a lot of exposure of English. The finding is also in line with Alberth (2018) that language learners have to be confident to use language especially in communication without too much worry about grammar and language structure. This findings further respond to gaps and suggestions given by Fan (2019) that identifying the learners' problems is not enough; thus, it is important to seek for the potential solutions. This study has closed this gap by offering possible solution of the challenges that International students encounter when studying abroad.

The results of this study provide several implications to the field of educational efficacy of international students. First, by examining Indonesian students' perceptions in Australian educational environment, it provides insights for other international learners that are going to study or having a study abroad. Second, other international learners may look at how the participants of this study deal with the challenges and difficulties they encounter during the study in overseas country. Third, educators or teachers may use the results of this study as insights to provide particular treatment for international students amidst the process of teaching and learning, despite of various differences including cultural backgrounds, levels of language proficiency, and learning styles.

\section{Conclusion}

The present study aims to explore Indonesian learners' perceptions, challenges, and resilience of having study abroad in Australia. Having eight Indonesian learners studying at several universities in Australia as participants, the results depicted that 
most of them perceived positive perception toward learning in Australian education context. They mentioned that language issue and learner autonomy became particular challenges to adapt to the Australian learning environment. As for the alternative solution, the participants mentioned that having English practices and building selfconfidence are highly necessary to do to deal with these challenges. These results contribute to offering references for teachers and educators to create suitable design of learning activities based on international students and interests. Apart from the compelling results, this study acknowledges that the research participants could not represent the whole population of international students in Australia. Therefore, further inquiries are highly necessary to be conducted by involving greater number of participants and various instruments of data collection, in addition to the interviews that had been used in this study.

\section{Acknowledgements}

Gratitude and acknowledgement go to all Indonesian learners studying in Australia who were willingly to be the participants in this research.

\section{References}

Alberth. (2018). Indonesian high school student motivational orientations for learning english as a foreign language: Some preliminary findings. Electronic Journal of Foreign Language Teaching, 15(2), 304-321.

Ambrose, M., Murray, L., Handoyo, N. E., Tunggal, D., \& Cooling, N. (2017). Learning global health: a pilot study of an online collaborative intercultural peer group activity involving medical students in Australia and Indonesia. BMC Medical Education, 17(1), 1-11.

de Britto, J.S. (2019). 5 Negara Paling Diminati Pelajar dan Mahasiswa Indonesia. Kaldera News, April 30, 2019. Retrieved from https://www.kalderanews.com/2019 /04/5-negara-paling-diminati-pelajar-dan-mahasiswa-indonesia/

Dewi, A. (2017). The English (es) to teach after study and life in Australia: A study of Indonesian English language educators. Asian Englishes, 19(2), 128-147.

Du, X., Zhao, K., Ruan, Y., Wang, L., \& Duan, X. (2017). Beginner CFL learners' perceptions of language difficulty in a task-based teaching and learning (TBTL) environment in Denmark. System, 69, 108-120.

Efendi, F., Oda, H., Kurniati, A., Hadjo, S. S., Nadatien, I., \& Ritonga, I. L. (2020). Determinants of nursing students' intention to migrate overseas to work and implications for sustainability: The case of Indonesian students. Nursing \& Health Sciences. 2020, 1-10. https://doi.org/10.1111/nhs.12757

Fan, J. (2019). Chinese ESL Learners' Perceptions of English Language Teaching and Learning in Australia. English Language Teaching, 12(7), 139. https://doi.org/10.5539/elt.v12n7p139

Fenanlampir, A., Batlolona, J. R., \& Imelda, I. (2019). The struggle of Indonesian students in the context of TIMSS and PISA has not ended. International Journal of Civil Engineering and Technology, 10(2), 393-406.

Hembrough, T., \& Jordan, J. (2020). Creating a digital writing classroom: A mixed methods study about a first-year composition tablet initiative. International Journal of Instruction, 13(2), 567-586. https://doi.org/10.29333/iji.2020.13239a

International Student Enrollment Data. (2016). International Student Data. Melbourne: Author. Retrieved April 25, 2017, from https://internationaleducation.gov.au/research/InternationalStudentData/Pages/InternationalStudentData2016.aspx

Lai, C., Wang, Q., Li, X., \& Hu, X. (2016). The influence of individual espoused cultural values on self-directed use of technology for language learning beyond the classroom. Computers in Human Behavior, 62, 676-688. 
https://doi.org/10.1016/j.chb.2016.04.039

Lopez, I. Y., \& Bui, N. H. (2014). Acculturation and Linguistic Factors on International Students' Self Esteem and Language Confidence. Journal of International Students, 4(4), 314-329

Mitchell Jr, D., Steele, T., Marie, J., \& Timm, K. (2017). Learning race and racism while learning: Experiences of international students pursuing higher education in the Midwestern United States. AERA Open, 3(3), 2332858417720402.

Mukminin, A. (2012). A phenomenological study of Indonesian graduate students' experiences on the acculturation process at an American University. Ph.D. Dissertation. The Florida State University.

Mulyana, D., \& Murtiningsih, B. S. E. (2017). Indonesian students cross cultural adaptation in Busan, Korea. Jurnal Aspikom, 3(2), 144-156.

Naghdipour, B. (2017). 'Close your book and open your facebook': A case for extending classroom collaborative activities online. Journal of Asia TEFL, 14(1), 130-143. https://doi.org/10.18823/asiatefl.2017.14.1.9.130

Nguyen, C. T. (2011). Challenges of Learning English in Australia towards Students Coming from Selected Southeast Asian Countries: Vietnam, Thailand and Indonesia. International Education Studies, 4(1), 13-20.

Novera, I. A. (2004). Indonesian postgraduate students studying in Australia: An examination of their academic, social and cultural experiences. International Education Journal, 5(4), 475-487.

Nugroho, A. (2020). Content and Language Integrated Learning Practice in English for Accounting Course. IJET (Indonesian Journal of English Teaching), 9(2), 172-181. https://doi.org/10.15642/ijet2.2020.9.2.172-181

Nugroho, A., \& Atmojo, A. E. P. (2020). Digital learning of english beyond classroom: EFL learners'perception and teaching activities. Jeels (Journal of English Education and Linguistics Studies), 7(2), 219-243.

Nugroho, A., \& Rekha, A. (2020). Speech Acts of Requests: A Case of Indonesian EFL Learners. Journal of English Language Teaching and Linguistics, 5(1), 1-16.

Paton, M. J. (2007). Why international students are at greater risk of failure: An inconvenient truth. Journal of Diversity in Organizations, Communities, and Nations, 6(6), 321-324

Sawir, E. (2005). Language difficulties of international students in Australia: The effects of prior learning experience. International Education Journal, 6(5), 567-580

Sawir, E., Marginson, S, Forbes-Mewett, H., Nyland, C., \& Ramia, G. (2012). International student security and English language proficiency. Journal of Studies in International Education, 20(2), 1-21.

Scarino, A. (2012). A rationale for acknowledging the diversity of learner achievements in learning particular languages in school education in Australia. Australian Review of Applied Linguistics, 35(3), 231-250.

$\mathrm{Yu}$, B., \& Wright, E. (2016). Socio-cultural adaptation, academic adaptation and satisfaction of international higher degree research students in Australia. Tertiary Education and Management, 22(1), 49-64.

Zulferdi, L. A. (2021). The English Use of Indonesian Students in Australia: Expectations, Perceptions, and Strategies. Journal of Foreign Language Teaching and Learning, 6(1), 1-19. 